\title{
Regelingen voor collectieve schade
}

\author{
Twee voorbeelden uit de jeugdzorg
}

\author{
Dr. C.J.Ruppert*
}

\begin{abstract}
1. Inleiding
De Nederlandse overheid treedt steeds meer op na collectieve schade. Het gaat om situaties waarin groepen mensen materiële en immateriële schade opgelopen hebben. Sinds de Tweede Wereldoorlog heeft de Nederlandse overheid voor dit soort situaties allerlei schaderegelingen gemaakt. Het overgrote deel van deze schaderegelingen wordt uit de publieke middelen gefinancierd. Onlangs is een onderzoeksrapport verschenen waarin ik de 44 Nederlandse regelingen voor collectieve schade heb geanalyseerd. ${ }^{1}$ Het betreft een heel heterogeen veld, dat loopt van Joodse oorlogstegoeden, seksueel misbruik in de jeugdzorg, chroom-6 en de vuurwerkramp Enschede tot de toeslagenaffaire en de mijnbouwschade Groningen. De algemene uitkomst van deze studie is dat veel van deze regelingen hun doel voorbijschieten. Ze zijn niet goed doordacht en onvoldoende uitgewerkt. Ook geven ze slachtoffers lang niet altijd voldoende erkenning voor wat hun is overkomen. Ten slotte lijkt de overheid elke keer het wiel weer uit te vinden.
\end{abstract}

Het gaat om zeer uiteenlopende gebeurtenissen, waarbij de overheidsverantwoordelijkheid soms heel nauw en direct is en soms beperkt en afstandelijk. Ik heb 44 regelingen onderscheiden, die te maken hebben met de volgende thema's:

1. Tweede Wereldoorlog;

2. aanvulling rechtsherstel;

3. geweld en zeden;

4. arbeids- en leefomstandigheden;

5. rampen en calamiteiten;

6. onjuiste wetstoepassing en onrechtmatig handelen door de overheid; en

7. internationale operaties Defensie.

Ik kan in dit artikel niet het hele onderzoeksrapport samenvatten. Interessant voor de lezers van TVP lijkt mij het gehanteerde beoordelingskader, dus de maatstaf waarmee naar de collectieve schaderegelingen is gekeken (par. 2). Getracht is om daarin de achterliggende doelen te vangen die voor elke schaderegeling zouden moeten gelden. Daarna bespreek ik de schaderegelingen die er gekomen zijn na onderzoeksrapporten

Dr. C.J. Ruppert is rechtshistoricus en gastonderzoeker bij het Nederlands Studiecentrum Criminaliteit en Rechtshandhaving te Amsterdam.

1 C.J. Ruppert, Regelingen voor collectieve schade. Geef slachtoffers erkenning, Den Haag: Boom juridisch 2021. Dit rapport is open access beschikbaar op de website van het NSCR, https://nscr.nl/app/ uploads/2021/11/NSCR_Regelingen-Collectieve-Schade_181121.pdf. over seksueel misbruik en geweld in de jeugdzorg (par. 3). De commissie-Samson en de commissie-De Winter brachten in 2012 respectievelijk 2019 hun eindrapporten uit. ${ }^{2}$ Van beide commissies was ik secretaris. De regering kwam na beide rapporten met een beleidsreactie, waarvan het voorstel voor een schaderegeling deel uitmaakte. Van deze schaderegelingen zal ik de aanleiding, de uitvoering en de gevoerde discussies beschrijven (par. 4). Daarna geef ik mijn belangrijkste conclusie over deze twee regelingen weer (par. 5).

Ik sluit dit artikel af met enkele lessen voor de overheid, als zij in de toekomst nieuwe collectieve schaderegelingen overweegt (par. 6). Die lessen heb ik ontleend aan alle onderzochte collectieve schaderegelingen. De belangrijkste aanbeveling is om erkenning een veel prominentere plaats in een schaderegeling te geven. Het is een goede les voor de overheid om te luisteren en zo veel als mogelijk aan te sluiten bij wat slachtoffers wensen. ${ }^{3}$

\section{Een beoordelingskader}

Bij een collectieve schaderegeling wordt allereerst geprobeerd om bij het optreden van schade voor iemand de oude situatie te herstellen, dat wil zeggen iemand krijgt restitutie van een goed of tegoed, of wordt in zijn rechten hersteld. Als dat niet kan, wordt gepoogd om iemand de materiële en immateriële schade te compenseren. Ten slotte wordt gepoogd om erkenning te geven aan slachtoffers. Voor bijna alle slachtoffers staat dat centraal. Nadere uitleg is daarom nodig over wat precies onder erkenning verstaan wordt (zie figuur 1$){ }^{4}$

2 Commissie-Samson, Omringd door zorg, toch niet veilig. Seksueel misbruik van door de overheid uit buis geplaatste kinderen, 1945 tot beden, Amsterdam: Boom 2012. Dit rapport is open access beschikbaar op de website van de rijksoverheid, www.rijksoverheid.nl/documenten/ rapporten/2014/02/06/rapport-commissie-samson-omringd-door-zorgtoch-niet-veilig; Commissie Onderzoek naar Geweld in de Jeugdzorg, Onvoldoende beschermd. Geweld in de Nederlandse jeugdzorg van 1945 tot heden, Den Haag 2019. Dit rapport is open access beschikbaar op de website van de rijksoverheid, www.rijksoverheid.nl/documenten/ rapporten/2019/06/12/onvoldoende-beschermd-geweld-in-denederlandse-jeugdzorg-van-1945-tot-heden.

3 Ruppert 2021, p. 92.

4 Ruppert 2021, p. 25-27. 
Figuur 1 Beoordelingskader

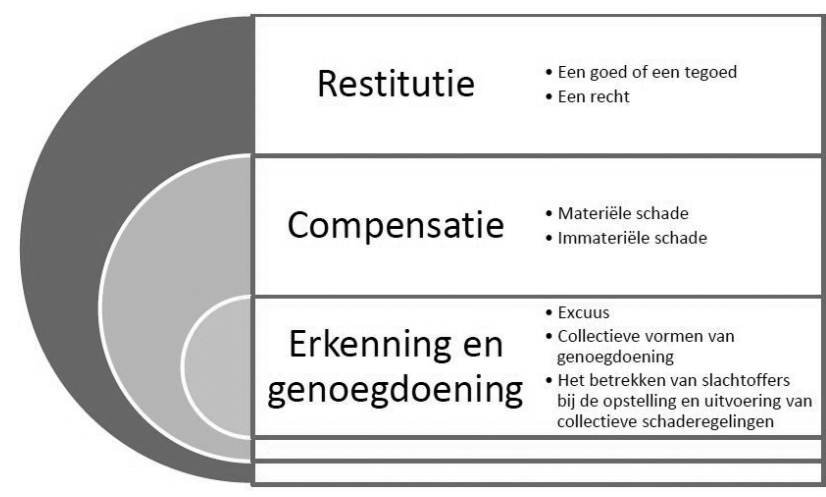

Bij erkenning en genoegdoening gaat het allereerst om het onomwonden uitspreken van een helder excuus. Alhoewel we in een tijdperk van een toenemend uitspreken van publieke excuses leven, is het essentieel dat excuses duidelijk geformuleerd worden. ${ }^{5}$ De betekenis van publieke excuses is groot, aldus advocate Liesbeth Zegveld, die al vaak van de overheid in spraakmakende kwesties excuses geëist heeft. Zegveld zegt het zo:

'Met excuses verbind je heden en verleden, waardoor het weer een geheel wordt en mensen rust vinden.'

\section{Historicus Henri Beunders voegt eraan toe:}

'Formele, gemeende excuses zorgen ervoor dat je als land niet blijft hangen in woede, rouw of schuldbesef, maar dat je elkaar een hand kunt geven. Zodat je verder kunt in een inclusieve samenleving waarin er plek is voor iedereen. ${ }^{6}$

Dan is wel weer belangrijk hoe je een excuus vormgeeft, welke locatie je kiest en welke non-verbale communicatie je gebruikt. Daaruit blijkt de oprechtheid die essentieel is voor de aanvaarding van je excuus, aldus Beunders. Voor zeer veel slachtoffers is het helder uitspreken van een publiek excuus door een gezagsdrager veel belangrijker dan het ontvangen van een financiële genoegdoening.

Naast excuses zijn er andere vormen van erkenning en genoegdoening. Zo willen veel slachtoffers dat hun verhalen in de toekomst blijvend gehoord en verteld kunnen worden. Een vorm die daarbij past en vaak genoemd wordt door slachtoffers zijn fysieke en digitale monumenten. Zo kan een zich ontwikkelende datacollectie van belang zijn in het kader van oral history, empowerment, maatschappelijke erkenning en weten-

5 M. Gibney, The age of apology: Facing up to the past, Philadelphia: University of Pennsylvania Press 2008; O. Zihlmann, Politik der Demut. Öffentliche Entschuldigungen für historisches Unrecht 1987-2006. Die Entstebung einer globalen Entschuldigungsbewegung zur Jabrtausendwende (diss. Basel), 2008.

6 'Nederland is niet zo goed in sorry zeggen', NRC 4 mei 2021. schappelijk onderzoek. ${ }^{7}$ Daarnaast zijn publiek besef en educatie een doelstelling van zulke initiatieven. Een laatste vorm van erkenning en genoegdoening ligt op een wat ander vlak, namelijk dat het hulpaanbod aan slachtoffers op verschillende niveaus op orde is.

Erkenning en genoegdoening houden ook in dat slachtoffers betrokken worden bij de opstelling en uitvoering van collectieve schaderegelingen. Bij een goede interactie met slachtoffers worden beslissingen, ook als zij negatief zijn voor slachtoffers, eerder 'aanvaard' als de procedure rechtvaardig is geweest. ${ }^{8}$ Ook kan met slachtofferparticipatie worden voorkomen dat schaderegelingen technisch, juridisch, bureaucratisch en adversarieel worden. Als de aanvrager om veel feiten wordt gevraagd en daar de bewijslast gelegd wordt, kunnen de regelingen immers een steen des aanstoots worden en tot gevoelens van secundaire victimisatie leiden. Al helemaal bij onrecht uit het verleden, omdat alleen al het tijdsverloop vaak aan het voldoen aan een 'normale' bewijslast in de weg staat.

\section{Seksueel misbruik en geweld in de jeugdzorg, 1945-heden}

De afgelopen tien jaar zijn er twee grote onderzoeken geweest die gericht waren op seksueel misbruik en geweld in de jeugdzorg in de periode 1945-heden. Het eerste onderzoek naar seksueel misbruik stond onder leiding van oud-procureur-generaal Rieke Samson (2010-2012). Het tweede onderzoek naar geweld stond onder leiding van oud-hoogleraar pedagogiek Micha de Winter (2015-2019). De hoofdboodschap (en de titel) van het eindrapport van de commissie-Samson was dat kinderen in de jeugdzorg die onder het toezicht van de overheid stonden over de gehele periode vanaf 1945 'Omringd door zorg, toch niet veilig' waren. De titel van het eindrapport van de commissie-De Winter was simpelweg 'Onvoldoende beschermd'. De belangrijkste uitkomst van het rapport lag al in de titel van haar eindrapport verscholen. Jeugdzorg was onvoldoende in staat om seksueel kindermisbruik te onderkennen en adequaat in te grijpen. De overheid bleef jarenlang op afstand, een beeld dat ook na 1990 niet wezenlijk veranderd was.

De commissie-Samson rapporteerde dat veel seksueel misbruik in de periode 1945 tot 2012 plaatsvond in een algemene context van geweld. Het seksueel misbruik was incidenteel en niet structureel van aard. Gingen voor 1975 vooral groepsleiders en pleegvaders in de fout, na 1975 kwam het seksueel misbruik steeds meer van de kant van leeftijdsgenoten. Het seksueel misbruik werd in de gehele periode weinig opgemerkt. De overheid bleef in situaties waarin seksueel misbruik voor-

7 S. Scagliola, 'Advies over hoe de methode Oral History kan worden ingezet ten behoeve van onderzoek naar voorkomen en gevolgen van geweld in de jeugdzorg', in: Bijlagen Commissie Vooronderzoek naar Geweld in de Jeugdzorg, Den Haag 2016, p. 411-434.

8 K. Daly, Redressing institutional abuse of children, Basingstoke: Palgrave Macmillan 2014; P. McCold \& T. Wachtel, In pursuit of paradigm: A theory of restorative justice, Rio de Janeiro 2003. 
kwam, op afstand en de sector bleef in gebreke. De commissie-Samson beschreef wel een algemene context van geweld, maar daar was de focus wat minder sterk op gericht. Het meldpunt en het onderzoek van de commissie-Samson hebben vooral inzicht gegeven in de aard, de omvang en de gevolgen van seksueel misbruik, hoe het kon gebeuren, en wat de reactie van de overheid daarop was geweest.

Bij een schatting van de omvang van seksueel misbruik in 2011 bleek dat het risico in de residentiële jeugdzorg 2,5 keer hoger was dan bij de nog thuiswonende Nederlandse jeugdigen. In instellingen voor kinderen met een licht verstandelijke beperking (LVB) bleek dat risico nog drie keer hoger (dan in instellingen die zich niet richten op de LVB-populatie). Kinderen in pleeggezinnen liepen veel minder risico op seksueel misbruik dan kinderen in instellingen.

De commissie-De Winter werd in 2015 ingesteld door het kabinet, toen slachtoffers van geweld zich gemeld hadden. Het seksueel misbruik was minder dominant in hun verhalen, meer het permanente geweld dat hun ten deel was gevallen als kind in de jeugdzorg. Het geweld was van fysieke, psychische en seksuele aard geweest. De commissie-De Winter makte een onderscheid tussen deze vormen van geweld en constateerde dat diverse vormen van geweld gelijktijdig en tezamen konden voorkomen. Uit een groot bevolkingsonderzoek bleek dat $10 \%$ van de mensen die na 1945 als kind in de jeugdzorg verbleven nooit met geweld te maken had gehad. Daar stond tegenover dat ongeveer $10 \%$ rapporteerde vaak tot zeer vaak geweld ervaren te hebben. Ook was opvallend dat mensen vooral het psychische geweld noemden dat hun als kind overkomen was. In de loop der jaren was er een verschuiving naar steeds meer psychisch geweld. In hun verdere leven hebben zij dat als een last meegedragen. Dat heeft voor hen tot allerlei negatieve gevolgen geleid. Die lagen vooral op psychisch vlak en het aangaan van intieme en sociale contacten.

De commissie-De Winter gaf dezelfde verklaringen als de commissie-Samson voor het zich voordoen van geweld. Kinderen verbleven tot in de jaren zeventig in te grote groepen, waardoor er te weinig toezicht en aandacht voor hen was. Er waren op veel gebieden tekorten; zo was er sprake van niet-opgeleid en te veel wisselend personeel in de instellingen, waardoor pedagogische continuïteit ontbrak. Ook was er een tekort aan pleeggezinnen, waar gemiddeld genomen de veiligheid voor kinderen beter was. Bovendien waren de normen over wat toelaatbaar was aan geweld ('de pedagogische tik') in de loop der decennia veranderd. De Nederlandse wet- en regelgeving droeg zeer lange tijd niet bij aan een eenduidig begrip van wat wel en niet toelaatbaar werd geacht ten aanzien van geweld tegen kinderen. Ook de strafbaarheid van geweld werd in verhouding met de strafbaarheid van seksueel misbruik pas laat geregeld.

Het interne en externe toezicht op instellingen en pleeggezinnen ontbraken in veel gevallen. Gezinsvoogden oefenden te weinig hun toezichthoudende rol uit. De Inspectie (Gezondheidszorg en) Jeugdzorg kwam weinig in de instellingen. Beide commissies concludeerden ook dat de regelgeving die vanaf de jaren negentig van de grond kwam, vooral een formele werkelijkheid van veiligheid (meldcodes) heeft gecreëerd. Er was geen sprake geweest van daadwerkelijke verbeteringen, dat wil zeggen vermindering van geweld. Er was een formele werkelijkheid opgetuigd met meldcodes, waarbij het kind en de echte pedagogische relatie van de groepsleider met het kind uit het zicht verdwenen.

Het merendeel van de aanbevelingen van beide commissies had betrekking op het in de toekomst voorkomen van seksueel misbruik en geweld in de jeugdzorg. Die blijven hier buiten beschouwing, centraal staan de voorstellen voor slachtoffers van geweld in de jeugdzorg in het verleden. ${ }^{?}$

De commissie-Samson merkte op dat slachtoffers behoefte hadden aan erkenning en excuus van besturen van instellingen. De commissie meende dat de huidige bestuurders erkenning moesten geven en excuses moesten aanbieden, ook voor misbruik uit het verleden. Daarbij paste niet dat zij zich verschuilen achter gebrekkige en/of afwezige dossiers. De commissie-Samson had het ingevolge haar opdracht niet tot haar taak gerekend een uitspraak te doen over mogelijke financiële genoegdoening aan de slachtoffers. De commissie-De Winter was concreter met haar aanbevelingen:

1. het bieden van erkenning aan slachtoffers;

2. het toegankelijk houden en uitbreiden van jeugdzorgarchieven vanwege maatschappelijke erkenning en wetenschappelijk onderzoek (oral history); en

3. het verbeteren van het hulpaanbod. ${ }^{10}$

De commissie-De Winter onderscheidde collectieve vormen van erkenning (fysieke en digitale monumenten) en meer individuele vormen van erkenning. Naast het krijgen van excuses zouden slachtoffers ook kunnen worden gecompenseerd in de vorm van een schaderegeling.

$\mathrm{Na}$ beide rapporten formuleerde de regering een excuus. $\mathrm{Na}$ Samson:

'Wij erkennen volledig het leed dat de slachtoffers is aangedaan. Wij bekijken op basis van de aanbevelingen van de Commissie hoe we op passende wijze tegemoet kunnen komen aan de verschillende behoeften aan hulp en ondersteuning die bij de slachtoffers leven.' ${ }^{11}$

\section{$\mathrm{Na}$ De Winter:}

'Zeker anno 2019 vinden wij het niet te bevatten dat deze kinderen, aan wie juist een veilige omgeving geboden had moeten worden, geen veiligheid en geborgenheid hebben

9 Commissie-Samson 2012, p. 120.

10 Commissie Onderzoek naar Geweld in de Jeugdzorg 2019, p. 93-96.

11 Kamerstukken II 2012/13, 33435, nr. 1. 
gevonden. In plaats daarvan kregen zij te maken met soms ernstig en veelvuldig fysiek en psychisch geweld. En dat terwijl het vaak ging om kwetsbare kinderen die al een uithuisplaatsing en wat daaraan voorafging hadden meegemaakt. Dit geweld vinden wij extra pijnlijk, omdat veel mensen daar tot op de dag van vandaag last van hebben. Dit geweld had niet mogen plaatsvinden. Excuses, erkenning, hulp en ondersteuning van de overheid voor deze slachtoffers zijn hier op zijn plaats.' ${ }^{12}$

Ook merkte de regering op dat, terugkijkend op wat in de periode vanaf 1945 gebeurd is, de verantwoordelijken voor kinderen in de jeugdzorg destijds te weinig hadden gedaan om geweld te voorkómen en te doen ophouden.

De slachtoffergroepen hadden in 2013 kortstondig contact met het Ministerie van Volksgezondheid, Welzijn en Sport (VWS) en het Ministerie van Veiligheid en Justitie over een breder pakket van maatregelen voor slachtoffers, zoals ook de commissie-Samson en de commissie-De Winter voorgesteld hadden. Het zogeheten Koershuisplan werd echter niet gerealiseerd. Wel kreeg één van de groepen een kortstondige subsidie. De situatie herhaalde zich in 2020, toen VWS en het Ministerie van Justitie en Veiligheid een projectorganisatie in-

12 Kamerstukken II 2019/20, 31015 en 31839, nrs. 174 en 178. richtten om de aanbevelingen door te voeren. ${ }^{13}$ In de praktijk kwam tot nu toe alleen een nieuwe schaderegeling van de grond. Ook is het de bedoeling dat een Nationaal Monument Geweld Jeugdhulp gerealiseerd wordt.

\section{De schaderegelingen Samson en De Winter}

De regering besloot na het rapport Samson tot twee schaderegelingen (zie tabel 1). ${ }^{14}$ In de ene regeling ('het Statuut') moesten claimanten met bewijsstukken (schriftelijk of via mondelinge getuigenissen van derden) aantonen dat zij het slachtoffer waren geweest van seksueel misbruik. Daar kwam als essentiële voorwaarde bij dat claimanten zelf moesten bewijzen dat jeugdzorg destijds op de hoogte was geweest van het misbruik (feitelijke wetenschap). Een commissie oordeelde of de claim toegekend werd. Als dat het geval was, moest de jeugdzorginstelling het bedrag aan de claimant betalen. De commissie bepaalde ook de hoogte van het schadebedrag. Als een jeugdzorginstelling feitelijke wetenschap ontkende en bewijzen ontbraken, werd de claimant afgewezen voor het Statuut en verwezen naar de andere regeling, de zogenoemde Tijdelijke Regeling, waar alleen getoetst werd op aannemelijkheid.

13 Zie www.rijksoverheid.nl/documenten/kamerstukken/2020/10/27/ kamerbrief-over-voortgang-maatregelen-commissie-de-winter.

14 Stcrt. 2013, 23822; zie https://wetten.overheid.nl/BWBR0044414/2021 01-01.

Schaderegelingen Samson en De Winter

\begin{tabular}{|c|c|c|c|c|c|c|c|}
\hline & Jaar & Doelgroep & $\begin{array}{l}\text { Type } \\
\text { schade }\end{array}$ & $\begin{array}{l}\text { Hoogte } \\
\text { uitkering }\end{array}$ & Restitutie & $\begin{array}{l}\text { Compen- } \\
\text { satie }\end{array}$ & $\begin{array}{l}\text { Erkenning } \\
\text { en } \\
\text { genoeg- } \\
\text { doening }\end{array}$ \\
\hline $\begin{array}{l}\text { Statuut voor de buiten- } \\
\text { gerechtelijke afhandeling } \\
\text { van civiele vorderingen } \\
\text { tot schadevergoeding in } \\
\text { verband met seksueel } \\
\text { misbruik van minderjari- } \\
\text { gen in instellingen en } \\
\text { pleeggezinnen }\end{array}$ & 2013 & $\begin{array}{l}\text { Kinderen die van } 1945 \\
\text { tot heden in de jeugd- } \\
\text { zorg verbleven en daar } \\
\text { seksueel misbruik } \\
\text { ondergingen }\end{array}$ & Immaterieel & $\begin{array}{l}€ 5.000- \\
100.000\end{array}$ & N.v.t. & Deels & Deels \\
\hline $\begin{array}{l}\text { Tijdelijke regeling } \\
\text { uitkeringen seksueel } \\
\text { misbruik minderjarigen } \\
\text { in instellingen en } \\
\text { pleeggezinnen }\end{array}$ & 2013 & $\begin{array}{l}\text { Kinderen die van } 1945 \\
\text { tot heden in de jeugd- } \\
\text { zorg verbleven en daar } \\
\text { seksueel misbruik } \\
\text { ondergingen }\end{array}$ & Immaterieel & $\begin{array}{l}€ 1.000- \\
35.000\end{array}$ & N.v.t. & Deels & Deels \\
\hline $\begin{array}{l}\text { Tijdelijke regeling } \\
\text { financiële tegemoetko- } \\
\text { ming voor slachtoffers } \\
\text { van geweld in de } \\
\text { jeugdzorg }\end{array}$ & 2020 & $\begin{array}{l}\text { Kinderen die van } 1945 \\
\text { tot heden in de jeugd- } \\
\text { zorg verbleven en daar } \\
\text { geweld ondergingen }\end{array}$ & Immaterieel & $€ 5.000$ & N.v.t. & Deels & Deels \\
\hline
\end{tabular}


De Tijdelijke Regeling was bedoeld om slachtoffers van seksueel misbruik, die niemand (meer) civielrechtelijk konden of wilden aanspreken, met een beperkte tegemoetkoming van overheidswege erkenning te bieden voor het leed dat hun was aangedaan. De bedoeling was dat de 'bewijslast' licht zou zijn. De betreffende commissie kon tot uitkering overgaan indien het voldoende aannemelijk was dat:

- seksueel misbruik had plaatsgevonden;

- het slachtoffer ten tijde van het seksueel misbruik minderjarig was en was geplaatst in een instelling of pleeggezin; en

- het seksueel misbruik gepaard ging met een geweldsaspect.

De Tijdelijke Regeling werd uit de overheidsmiddelen betaald.

Van de aanvragen werd $41 \%$ voor het Statuut afgewezen en $19 \%$ voor de Tijdelijke Regeling. Beide schaderegelingen werden in 2017 op verzoek van VenJ geëvalueerd door het onderzoeksbureau Cebeon. ${ }^{15}$ Een deel van de slachtoffers was van mening dat hun leed erkend was en dat zij door de toegekende tegemoetkoming in de schade ook enige genoegdoening hebben gekregen. Een ander deel vond dit juist niet. Zo konden excuses in principe alleen worden aangeboden als er contact was geweest met de verantwoordelijke jeugdzorginstelling, derhalve bij aanvragen op grond van het Statuut. Ook als er gelegenheid was geweest voor excuses, bleken deze niet altijd te zijn aangeboden door de jeugdzorginstelling. Of de financiële vergoeding werd niet altijd als genoegdoening ervaren, omdat men die te laag vond in relatie tot het aangedane leed en/of in relatie tot de praktische en emotionele inspanningen om de aanvraag te doen. Dat voor hetzelfde misbruik bij de Tijdelijke Regeling minder uitgekeerd werd dan bij het Statuut, beschouwden vele slachtoffers als onrechtvaardig. Ook de verschillende gehanteerde klassen werden als negatief beoordeeld. Daar kwam bij dat beide regelingen gebaseerd waren op het misbruik destijds en niet op de gevolgschade in het latere leven. Ook dat werd als onrechtvaardig beschouwd. De jeugdzorginstellingen op hun beurt vreesden voor de financiële gevolgen voor hun instellingen als zij 'het volle pond' moesten betalen en claimanten ook nog naar de rechter konden lopen.

Door het doorlopen van het aanvraagproces kreeg een deel van de aanvragers erkenning van het leed (bijvoorbeeld bij een hoorzitting of in het contact met het Schadefonds of Slachtofferhulp Nederland), maar dat gold niet voor iedereen. Die werden door een eventuele afwijzing diep geraakt. Voor hen was mogelijk sprake van secundaire victimisatie, waardoor zij (opnieuw) psychologische hulp hadden moeten zoeken. Een aantal hoofdpersonen van het Schadefonds, het Statuut en de Tijdelijke Regeling blikte terug en had dezelfde waarnemingen als Cebeon:

15 Cebeon, Erkenning, genoegdoening of opnieuw geraakt. Ervaringen met de financiële regelingen 'Seksueel misbruik in instellingen en pleeggezinnen', Amsterdam: Cebeon 2018. Dit rapport is open acces beschikbaar op de website van het WODC, https://repository.wodc.nl/ handle/20.500.12832/2278.
'[D]e eis van "feitelijke wetenschap" was dus niet alleen een zware, zij was ook contra-intuïtief voor de gegeven problematiek (...). Voor een aantal van hen zal gelden dat zij zich opnieuw slachtoffer hebben gevoeld. ${ }^{16}$

Zij wezen er ook op dat het proces van behandeling van de aanvragen inspannend en vaak ook belastend was geweest voor de aanvragers. Rieke Samson sprak zelf naderhand in interviews over een 'weeffout' in het Statuut, omdat de bewijslast van het misbruik en de feitelijke wetenschap ervan op voorhand bij de aanvrager gelegd waren. Alleen een verklaring van een claimant was namelijk niet voldoende om in aanmerking te komen voor het Statuut.

Het gemengde oordeel over de schaderegeling leidde er mede toe dat na het rapport De Winter door JenV een uniforme individuele schaderegeling werd gemaakt, de Tijdelijke regeling financiële tegemoetkoming voor slachtoffers van geweld in de jeugdzorg. ${ }^{17}$ Het uit te keren bedrag was een financiële tegemoetkoming en gold als erkenning voor het leed dat slachtoffers was aangedaan. Het was nadrukkelijk geen compensatie van kosten of schade voortkomend uit het toegebrachte leed. Er werd een eenvoudige bestuursrechtelijke regeling opgesteld met een bedrag dat vergelijkbaar was met bedragen die het Schadefonds Geweldsmisdrijven uitkeert voor psychisch letsel bij stelselmatig huiselijk geweld. De $€ 5.000$ was veel lager dan wat gemiddeld bij het Statuut ( $€ 54.400)$ en de Tijdelijke Regeling (€ 18.300) uitgekeerd werd. Minister Sander Dekker zei er in het debat op 16 december 2020 dit over:

'Bij de uiteindelijke beslissing voor de keuze van het bedrag speelde de overweging mee dat naarmate het bedrag hoger wordt natuurlijk ook de eisen rond de bewijslast toenemen, omdat daarmee ook de kans op misbruik weer toeneemt. Met andere woorden: we hebben moeten kiezen tussen een lage bewijslast en maatwerk. Het bleek heel moeilijk, eigenlijk onmogelijk, om die twee te verenigen. Daarom zijn we op dit voorstel, deze regeling, uitgekomen.' ${ }^{18}$

In een eerste reactie schreven de verzamelde organisaties van lotgenoten de Tweede Kamer de tegemoetkoming te algemeen en veel te summier te vinden. ${ }^{19}$ Ook voelden zij zich niet betrokken bij de totstandkoming van de regeling. Nadien hebben enkele meisjes van De Goede Herder de Tweede Kamer benaderd. Zij voelden zich niet erkend in hun leed omdat zij de vergoeding voor hen als slachtoffers van dwangarbeid te

16 L. Goossens, S.D. Lindenbergh, C.H.C.J. van Nijnatten \& M. Olff, ‘Op zoek naar genoegdoening. Uitvoering van de financiële regelingen voor slachtoffers van seksueel misbruik in de jeugdzorg', NJB 2019/23, p. 1673.

17 Kamerstukken II 2019/20, 31839, nr. 191.

18 Zie www.tweedekamer.nl/kamerstukken/plenaire_verslagen/detail/2020 $-2021 / 38$.

19 Zie stichtingskip.nl/images/downloads/16_maart_2020_Brief_Koers huis.pdf. 
mager vonden. ${ }^{20} \mathrm{Zij}$ overwogen een rechtszaak tegen de Staat te beginnen als het bedrag niet omhooggaat. In het Kamerdebat over het rapport De Winter op 16 december 2020 werden door de oppositie moties over de schaderegeling ingediend die beoogden het bedrag te verhogen of eerst te onderzoeken of het bedrag wel recht deed aan de werkelijk geleden schade. Deze werden alle bij stemming verworpen. ${ }^{21}$ Het Schadefonds Geweldsmisdrijven ging ook deze regeling uitvoeren. Voor de regeling meldden zich rond de zesduizend mensen. Dit aantal was veel groter dan verwacht, waardoor wachttijden van enkele maanden optraden. De Winter maakt zich hierover druk:

'We weten uit het verleden dat je bij dit soort regelingen mensen snel moet helpen. Het naarste is dat het op een lange termijn aan komt. Mensen denken dan: zie je wel ik tel niet meer mee, ik word weer op de lange baan geschoven. Dat wil je niet als overheid. Er moet alles aan gelegen zijn om dat te versnellen. ${ }^{.22}$

$85 \%$ van de drieduizend al behandelde aanvragen werd goedgekeurd.

\section{Belangrijkste conclusie over deze twee regelingen}

Mijn belangrijkste conclusie over de schaderegelingen Samson en De Winter is dat er wel geheel of gedeeltelijk gecompenseerd werd, maar dat slachtoffers slechts deels erkenning en genoegdoening kregen. De vraag dient zich daarom aan wat de legitimiteit van deze schaderegelingen is als zij juist geen of weinig erkenning en genoegdoening bieden aan de slachtoffers van seksueel misbruik en geweld in de jeugdzorg.

Er werd bij de Samson-schaderegelingen betaald door de jeugdzorginstelling of de overheid, maar sommige slachtoffers waren daarmee niet tevreden. De regelingen werden zelf voorwerp van discussie en beschadigden een deel van de slachtoffers. De regelingen schoten daardoor ten dele hun doel voorbij. Het slotoordeel van de officiële evaluatie door Cebeon loog er niet om:

'Wellicht kun je het als overheid of jeugdzorg in dezen nooit helemaal goed doen; het aangedane leed is te groot en onmogelijk te vertalen in een geldbedrag. Maar er zijn - zoals hierboven aangegeven - wel concrete elementen in de regelingen die het bereiken van de beoogde doelen onnodig hebben belemmerd. Hierdoor zijn er - naast slachtoffers die erkenning en genoegdoening hebben gekregen via de regelingen - ook slachtoffers die door het aanvragen van de regelingen opnieuw zijn geraakt. ${ }^{23}$

20 Kamerstukken II 2019/20, 31839, nr. 181.

21 Zie tweedekamer.nl/kamerstukken/stemmingsuitslagen/detail?id=2020 P20735.

$22 \mathrm{Zie}$ www.nationaleonderwijsgids.nl/speciaal-onderwijs/nieuws/59552wachttijden-van-langer-dan-een-half-jaar-bij-schadefonds-jeugdzorg. html.

23 Cebeon 2018, p. 94
Ik zou in mijn conclusie verder willen gaan. De regelingen hebben voor een deel van de slachtoffers contraproductief gewerkt en hen 'achterop geholpen'. Het is achteraf bezien een politieke en ook menselijke vergissing geweest om twee Samson-schaderegelingen te maken waarbinnen weer allerlei klassen onderscheiden werden, zodat er in feite onderscheid gemaakt werd tussen slachtoffers. Doordat slachtoffers zelf de aard en de ernst van het seksuele misbruik moesten bewijzen richting jeugdzorginstellingen of aannemelijk moesten maken richting de overheid, werd een proces van juridisering ingezet die niet gunstig uitwerkte voor de slachtoffers en zelfs naderhand tot rechtszaken tegen de overheid geleid heeft. De uitvoering van de regelingen door het Schadefonds Geweldsmisdrijven was op zichzelf gewetensvol en empathisch, maar 'de weeffout' van de schaderegelingen, zoals Rieke Samson dat in publieke optredens typeerde, was op voorhand ingebakken. Achteraf bezien was het beter geweest als er één uniforme schaderegeling was geweest zonder bewijslast, met slechts één bedrag dat door de overheid betaald was. Die schaderegeling had als tegemoetkoming van de overheid voor de geleden immateriële schade kunnen gelden.

De hoogte van dat gemiddelde bedrag zou altijd een politieke keuze zijn geweest. Bij de schaderegeling De Winter was wel sprake van een uniforme schaderegeling, die als tegemoetkoming geformuleerd was. Tegelijkertijd stond de uitgekeerde $€ 5000$ in een vreemde verhouding met de gemiddelde uitgekeerde bedragen bij de Samson-schaderegelingen. Een inhoudelijke rechtvaardiging van het lagere bedrag ontbrak en het budgettaire aspect leek hier de doorslag te hebben gegeven. Daarmee werd politiek en maatschappelijk de indruk gewekt dat in de geschiedenis van de jeugdzorg geweld van minder betekenis is geweest in het leven van slachtoffers dan seksueel misbruik. En dat verhield zich weer niet goed met de eindrapporten Samson en De Winter, waarin bij voortduring gewezen werd op seksueel misbruik dat zich kon voordoen in een setting van geweld.

Daar komt iets bij. Omdat de slachtoffergroepen door de betrokken ministers slechts fragmentarisch bij de totstandkoming van deze regelingen werden betrokken en inspraak uitbleef, werden de schaderegelingen aan 'hen opgelegd'. De gevoerde Kamerdebatten over de regelingen leidden niet meer tot verandering van de voorgenomen regelingen. De schaderegelingen Samson en De Winter werden daarom nooit volledig omarmd door de slachtoffergroepen en met gepaste trots verdedigd naar hun achterbannen. Het ongenoegen van een deel van de slachtoffers bleef bestaan richting de overheid. De schaderegelingen Samson en De Winter werden als vrij kaal beoordeeld. Dit klemde temeer daar andere gewenste voorzieningen voor slachtoffers (blijvende financiële ondersteuning slachtoffergroepen, fysieke en digitale monumenten, beter hulpaanbod) in de praktijk amper van de grond kwamen. Dat was wel toegezegd in de officiële beleidsreacties op de rapporten Samson en De Winter. 


\section{Lessen voor de toekomst}

Er zijn enige lessen te trekken voor als de overheid in de toekomst weer regelingen bij collectieve schade overweegt. Die illustreer ik door enkele andere collectieve schaderegelingen aan te halen die op specifieke punten goed uitgewerkt hebben en waarvan te leren is.

Het is een eerste les om te luisteren en zo veel als mogelijk aan te sluiten bij wat slachtoffers wensen als collectieve schade opgetreden is. ${ }^{24}$ Vervolgens kunnen overheid en slachtoffers samen de weg bewandelen die uiteindelijk leidt tot een regeling. Geef de slachtoffers altijd zeggenschap in de voorbereiding en de uitvoering van de collectieve schaderegeling. Het zorgt voor draagvlak onder de doelgroep. Een voorbeeld van hoe zeggenschap in de praktijk kan uitwerken, leert de Joodse stichting Maror-gelden Overheid. De ontstaansgeschiedenis ligt in de akkoorden in 1999 en 2000 van de Joodse gemeenschap met de overheid en de financiële wereld over Joodse oorlogstegoeden. Behalve excuses, de erkenning van de morele aanspraken van de Joodse gemeenschap op restitutie, kreeg de Joodse gemeenschap $f 764$ miljoen. Net zo belangrijk was dat de Joodse gemeenschap grotendeels zelf het vervolg kon bepalen. In het voorjaar en de zomer van 2000 speelde een uitgebreide en soms ook felle discussie binnen de Joodse gemeenschap wie rechthebbende op de schaderegeling zou zijn (Joden, half-Joden, nabestaanden). Verder ging het om de verhouding van het bedrag dat naar individuele schade-uitkeringen zou gaan versus het bedrag voor collectieve Joodse doelen. Ook speelde een discussie over de verdeelsleutel van de collectieve gelden tussen Israël en Nederland. ${ }^{25}$ Besloten werd dat minimaal 80\% voor individuele uitkeringen beschikbaar zou zijn en dat de rest naar collectieve voorzieningen zou gaan. Volgens intern-Joodse afspraken werd van de collectieve gelden $74 \%$ bestemd voor Nederland en $26 \%$ voor Israël. ${ }^{26}$

Waar het Centraal Joods Overleg (CJO), dat overlegde met de Nederlandse overheid, in eerste instantie voor overwegend collectieve doelen was, schoof het onder druk van de achterban op naar hoofdzakelijk individuele uitkeringen. ${ }^{27}$ De Nederlandse overheid kon hiermee instemmen. Ook de organisatorische uitwerking van de verdeling van de schade-uitkeringen werd in een intern-Joodse werkgroep verricht. Aan deze discussies over het Uitkeringsreglement en de Statuten van Maror-gelden Overheid namen ook ambtenaren van de meest betrokken ministeries evenals de landsadvocaat deel. Het Uitkeringsreglement en de Statuten werden in de zomer van 2000 voorgelegd aan beide Kamers der Staten-Generaal. ${ }^{28} \mathrm{Het} \mathrm{Mi}-$ nisterie van Financiën zou enige jaren toezicht uitoefenen en

24 Ruppert 2021, p. 92-93.

25 Zie www.staal.bz/Books/Boek-1/RS/Noten/CJO/CJO-jaarverslag2000.pdf, p. 9-12.

26 Zie www.maror.nl/over-ons/oorsprong-maror-gelden.

27 C.J. Ruppert, Eindelijk restitutie. De totstandkoming van Nederlandse akkoorden over Joodse oorlogstegoeden (1997-2000) (diss. Amsterdam VU), 2017, p. 135-137 en 139-141.

28 Kamerstukken II 1999/2000, 25839, nrs. 15 en 20. daarvoor publieke verantwoording afleggen. ${ }^{29}$ De individuele schade-uitkeringen en de eerste twee jaarlijkse subsidierondes voor de collectieve voorzieningen in Nederland zijn gedaan onder toezicht van de overheid. Sinds 2005 ligt de verantwoordelijkheid voor de subsidieregeling ten behoeve van collectieve voorzieningen bij de private Stichting Collectieve Maror-gelden Nederland. De collectieve doelen hebben betrekking op sectoren als cultuur, media, onderwijs/educatie, religie, welzijn, jongeren, zorg, externe belangen en herinnering. ${ }^{30}$

Een tweede les is om de uitvoering van een collectieve schaderegeling niet bureaucratisch en formalistisch te doen verlopen. Belangrijk is dat slachtoffers zich daadwerkelijk gehoord en serieus genomen voelen door de uitvoerende instantie als zij een aanvraag doen voor een uitkering. Een voorbeeld van een goede en empathische uitvoering is het Schadefonds Geweldsmisdrijven. ${ }^{31}$ Dat keert een materiële en immateriële schadevergoeding uit aan slachtoffers van opzettelijke geweldsmisdrijven. Ook naasten en nabestaanden komen in aanmerking. De econome José Mulder deed onderzoek naar het Schadefonds Geweldsmisdrijven. In haar proefschrift uit 2013 concludeerde zij dat slachtoffers in ruime mate tevreden waren met zowel de gang van zaken bij het Schadefonds als de vergoeding die zij gekregen hadden. ${ }^{32}$ Bovendien bleken slachtoffers symbolische waarde aan het geld te ontlenen: slachtoffers voelden zich erkend en ervoeren een gevoel van gerechtigheid. Het doet hun goed. Mulder concludeerde:

'Opmerkelijk genoeg hebben deze effecten niets te maken met de hoogte van het ontvangen bedrag. Een tijdige afhandeling en persoonlijk contact zijn bepalend voor de tevredenheid van slachtoffers en het wel of niet ervaren van symbolische waarde. Niet het financiële bedrag an sich is dus van belang, maar de manier waarop slachtoffers het geld ontvangen. ${ }^{33}$

Een vergoeding van het Schadefonds ontvangen betekende 'gezien worden'. Mulder adviseerde het Schadefonds om de communicatie met slachtoffers te verbeteren en duidelijk uit te leggen wat slachtoffers zouden kunnen verwachten.

Een derde les is om in de uitvoering van de collectieve schaderegelingen ruimte te creëren waardoor uitzonderingen mogelijk zijn ten faveure van de slachtoffers. Juist collectieve schaderegelingen moeten met enige soepelheid worden uitgevoerd, zodat slachtoffers niet tegenover de collectieve schaderegeling

29 Kamerstukken II 1999/2000, 25839, nrs. 24 en 35.

30 In 2020 was het belegd vermogen ruim $€ 25$ miljoen en werd $€ 1,5$ miljoen uitgekeerd.

31 Ruppert 2021, p. 44-45.

32 J.D.W.E. Mulder, Compensatie na geweld. Wie krijgen er een vergoeding van het Schadefonds Geweldsmisdrijven en wat zijn de effecten van zo'n financiële vergoeding, Tilburg 2009; J.D.W.E. Mulder, Compensation: The victim's perspective (diss. Tilburg), Oisterwijk: Wolf Legal Publishers 2013.

33 Zie nemokennislink.nl/publicaties/slachtoffers-tevreden-met-bescheiden -schadevergoeding/. 
komen te staan. Dit is van belang als collectieve schaderegelingen allerlei onderscheidingen naar verschillende uitkeringshoogtes maken. Anders liggen teleurstellingen op de loer. De collectieve schaderegeling van de rooms-katholieke kerk heeft op dit punt goed uitgewerkt en kan als voorbeeld dienen voor andere regelingen. Mensen die ontevreden waren omdat zij afgewezen waren voor een uitkering of de toegekende uitkering te laag vonden, konden terecht bij het onafhankelijke Meldpunt Seksueel Misbruik Rooms-Katholieke Kerk. Het bleek een uiterst professionele organisatie te zijn voor hulpverlening, klachtenbehandeling en compensatie. Het aantal mensen dat hulp, erkenning en compensatie kreeg van het meldpunt was ruim tweeduizend.

Het meldpunt keek aan het einde van zijn werkzaamheden in 2018 terug op de verschillende regelingen. Bij de uitvoering van de klachtenregeling had volgens het klachtenbureau het belang van de slachtoffers vooropgestaan. De klachtenregeling had grosso modo aan de verwachtingen van de slachtoffers voldaan. ${ }^{34}$ Dit kwam onder meer tot uitdrukking in het feit dat verjaring en het overleden zijn van de vermoedelijke dader geen beletsel waren de klacht af te wijzen, en dat de klachtencommissie een lage bewijsdrempel hanteerde. Voldoende was dat de klacht aannemelijk was. Een alternatief voor de klachtenprocedure bleek mediation te zijn, waarvoor de rooms-katholieke kerk pas in een laat stadium koos. In bijna alle mediationzaken kwam het tot een daadwerkelijke bemiddeling, waarover de betrokken partijen na afloop over het algemeen positief waren. Een financiële compensatie makte soms wel en soms geen deel uit van het mediationtraject. ${ }^{35}$

Een vierde en laatste les ligt meer op het vlak van monitoring van collectieve schaderegelingen. Tot nu toe gebeurt dat te weinig. Het is zinvol als het verloop van collectieve schaderegelingen periodiek geëvalueerd wordt. Vervolgens ligt daar een opgave voor de overheid om zich daarmee te verantwoorden richting de Tweede Kamer. En - ook niet onbelangrijk - ligt er een opdracht aan de Tweede Kamer om op te blijven letten en bij te sturen waar dat nodig is. Dit maakt het mede mogelijk om adequate collectieve schaderegelingen te ontwikkelen die recht doen aan wat slachtoffers ooit is overkomen.

34 Meldpunt Seksueel Misbruik R.-K. Kerk in Nederland, Verslag van werkzaamheden 2011-2018, Utrecht: Livertas Pascal 2019, p. 9. Dit rapport is open access beschikbaar op de website van het Meldpunt Seksueel Misbruik, www.meldpuntmisbruikrkk.nl/S/Paginas/default.html.

35 Meldpunt Seksueel Misbruik R.-K. Kerk in Nederland 2019, p. 11. 